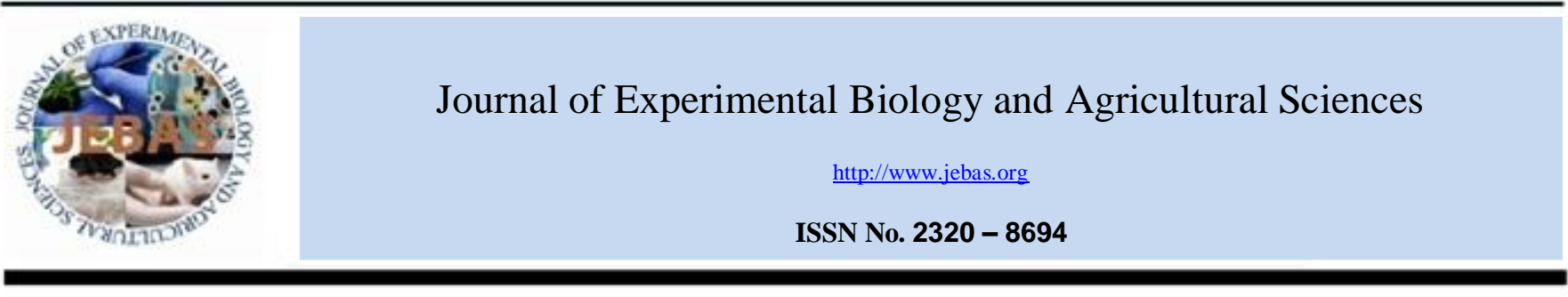

\title{
MOLECULAR CONFIRMATION OF SEX IN REGENERATED PLANTLETS OF SPINE GOURD (Momordica dioica Roxb. Ex. WILD) BY USING RAPD MARKERS
}

\author{
S. Raju ${ }^{1}$, Ravi Chithakari ${ }^{1}$, Prasad Bylla ${ }^{2}$ and Md. Mustafa ${ }^{3, *}$ \\ ${ }^{1}$ Research Scholar, Plant Tissue culture, Molecular and Taxonomy, Laboratory, Kakatiya University, Warangal, 506009, Telangana State, India. \\ ${ }_{2}^{2}$ Research Scholar, Plant Biotechnology laboratory, Department of Biotechnology, Kakatiya University Warangal, 506009, Telangana State, India \\ ${ }^{3}$ Asst. Professor, Department of Botany, Kakatiya University Warangal, 506009, Telangana State, India
}

Received - May 05, 2015; Revision - June 12, 2015; Accepted - October 01, 2015

Available Online - October 20, 2015

DOI: http://dx.doi.org/10.18006/2015.3(5).407.414

\section{KEYWORDS}

Embryogenic callus

Regenerated plantlets

Sex determination

RAPD primer

\begin{abstract}
Plant tissue culture techniques offer a great opportunity to overcome the limitations associated with the large scale cultivation of spine gourd. Present study was carried out to formulate the best possible media for large scale production of spine gourd and result of the study revealed that highest percentage (85\%) of embryogenic callus was obtained from MS medium supplemented with $2.0 \mathrm{mg} / \mathrm{L}$ each of 2, 4Dichlorophenoxyacetic acid (2, 4-D) and 6- Benzylamino Purine (BAP) in leaf explants of spine gourd. Maximum number of shoots (12.15 \pm 1.51 shoots) were observed on MS medium augmented with BAP $(4.0 \mathrm{mg} / \mathrm{L})$ in combination with L-glutamine $(2.0 \mathrm{mg} / \mathrm{L})$ from leaf derived embryogenic callus of spine gourd. Identification of sex by using morphological characters in the newly regenerated plantlets of spine gourd at fourth leaf stage is another problem for large scale propagation of female plants. PCR based molecular marker OPA-15, a Random Amplified Polymorphic DNA (RAPD) primer can be used as a differential marker to identify female plants form male plants at pre-flowering stage in newly regenerated plantlets (in vitro) and as well as in field plants (in vivo) of spine gourd. A unique amplification band (700 bp) in size appeared only in female samples, but not in male samples of spine gourd.
\end{abstract}

* Corresponding author

E-mail: : mustafarz67@gmail.com (Md. Mustafa)

Peer review under responsibility of Journal of Experimental Biology and Agricultural Sciences.

Production and Hosting by Horizon Publisher (www.myvision.webs.com/horizon.html).

All rights reserved.
All the article published by Journal of Experimental

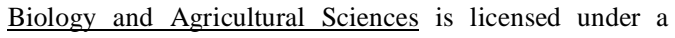
Creative Commons Attribution-NonCommercial 4.0 International License Based on a work at www.jebas.org.

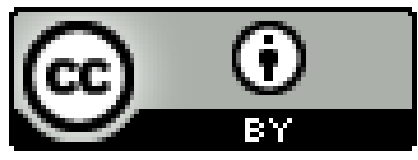




\section{Introduction}

Spine gourd (Momordica dioica Roxb. ex. wild) is a perennial, rhizomatous, dioecious climber belongs to cucurbitaceae family. This is a highly demandable seasonal vegetable and medicinal plant in Asian countries. This species is indigenous to India; because of its higher medicinal importance it is demandable vegetation throughout the world (De Wilde \& Duyfjes, 2002; Joseph, 2005; Joseph \& Antony, 2008). Spine gourd had various vernacular names in different regional languages of India viz; Akakara and Bodakakara in telugu, Kakor, Parora and Golbandra in Hindi, Dharkarela in Panjabi, Batkarila in Assami, Banzakartoli in Marathi, Kartoli in Bengali, Aegaravalli, Toloopavai and Palupaharkai in Tamil, Erimapasel, Venpaval in Malayalam, Adavihagal and Madahagala-Kayi in Kannada and Vahisi in Sanskrit (Bawara et al., 2010). Fruit of spine gourd are free from cholesterol and are highly energetic $(45.74 \mathrm{Kcal}$.) with adequate amount of water $(84 \%)$, protein $(3.1 \mathrm{~g})$ and important minerals and vitamins (Gopalan et al., 1994; Ram et al., 2004; Aberoumand $\&$ Deokule, 2009). The medicinal importances of spine gourd are sex-specific and only female plants have medicinal values (Sastri et al., 1962). Kumar \& Prajapati (2003) reported that the fruit giving plants have its own value in preparation of medicines and leaves of female spine gourd are used as an aphrodisiac, to eliminate the parasites present in the human intestine, cure fever and respiratory disorders. Furthermore, Kumar \& Prajapati (2003) stated that root tubers are used for the treatment of headaches, kidney stones and jaundice. Medicinal value of this plant was also reported by Jain \& Singhai (2010) also these researchers reported that fruits are useful in the treatment of asthma, leprosy, fever, tumors, urinary discharges, excessive salivation, and heart disease. Furthermore, Jain \& Singhai (2010) also noticed that fruit powder is used to induce sneezing, leading to nasal clearing.

Vegetative mode of propagation through root tubers, availability of root tubers to the farmers, very low percentage of seed germination $(10 \%)$, hard seed coat and seed prolonged dormancy (4 to 5 months) are the major hurdles for large scale cultivation of spine gourd. By using plant tissue culture technique it can be propagate rapidly and in large quantity within a short period of time. But there is another problem associated with the newly regenerated plantlets of spine gourd, that the identification of sex at very early stage of growth. RAPD - PCR technique offers a great opportunity to identify the sex of the newly regenerated plantlets. Therefore present study has been carried out for the formulation of effective tissue culture media for the better and rapid growth of spine gourd tissue. Furthermore, an effort of female plantlets identification at early stage of growth with the help of RAPD PCR was also carried out in present study.

\section{Materials and Methods}

\subsection{Plant materials}

Male and female plants of spine gourd were collected from different geographical locations viz Warangal, Karimnagar and Khammam districts of Telangana State and were grown in the research field of the Department of Botany, Kakatiya University, Warangal.

\subsection{Micropropagation}

Young and well matured leaves obtained from $M$. dioica plants are used in present investigation. Explants were sterilized with $0.1 \% \mathrm{HgCl}_{2}$ for 3-4 minutes then rinsed with double distilled water and inoculated on MS medium (Murashige \& Skoog, 1962) augmented with various concentrations of 2, 4 -D in combination with BAP $(0.5$ to $3.0 \mathrm{mg} / \mathrm{L}$ each $)$. The culture vessels were incubated and maintained at $25 \pm 2^{\circ} \mathrm{C}$ temperature and 16 hour light (3000 lux light intensity). After 3 weeks embryogenic compact callus with green spots was developed from the cut portion of the explant. These calli were sub cultured on MS medium fortified with BAP (1.0 to 5.0 $\mathrm{mg} / \mathrm{L})$ in combination with L-glutamine $(2.0 \mathrm{mg} / \mathrm{L})$. Newly regenerated micro shoots were transferred to IBA $(1.0 \mathrm{mg} / \mathrm{L})$ rooting medium, after 4 weeks of the cultures. The regenerated plantlets were acclimatized and transferred to field conditions.

2.3 Molecular Confirmation of Sex in Regenerated Plantlets by using RAPD markers:

By using RAPD - PCR technique the sex of the field grown plants (in vivo) had determined and these amplification results were comparing with the amplification results of in vitro developed plantlets and sex of newly regenerated plantlets (in vitro) of spine gourd had confirmed.

Known sex (male and female) type leaves of the mother plant and randomly selected in vitro regenerated plants at $4^{\text {th }}$ leaf stage of the plant were collected and used for RAPD - PCR amplification. Genomic DNA was isolated from juvenile leaves of the female and male mother plants (in vivo) and regenerated plants (in vitro) by using the protocol of Doyle \& Doyle (1990). The concentration of DNA was determined by a UV-Vis spectrophotometer and quality of genomic DNA was checked following electrophoresis on $0.8 \%$ agarose gel. RAPD assay was performed using 4 RAPD primers (Bioserve, Mumbia, India) (Table 3). PCR was performed in a volume of $21 \mu 1$ reaction mixture containing $2.0 \mu 1$ genomic DNA (80 ng), $2.0 \mu 1$ Taq buffer, $2.0 \mu 1$ dNTPs, $2.0 \mu 1 \mathrm{MgCl} 2,2.0 \mu 1$ random primer $(10 \mathrm{pM}), 1.5 \mu 1$ Taq DNA polymerase and 8.5 $\mu 1$ PCR grade water. DNA amplification was carried out in a DNA thermal cycler (My gene, USA). The PCR program was setup with an initial denaturation, denaturation, annealing, extension and final extension at $94^{\circ} \mathrm{C}$ for $3 \mathrm{~min}, 94^{\circ} \mathrm{C}$ for 45 seconds, $32^{\circ} \mathrm{C}$ for $30 \mathrm{sec}, 72^{\circ} \mathrm{C}$ for $2 \mathrm{~min}$ and $72^{\circ} \mathrm{C}$ for $7 \mathrm{~min}$, respectively (Table 4 ). The amplified products of DNA were analyzed by gel Agarose gel electrophoresis, $\lambda$ DNA used as a molecular marker and visualized by staining with ethidium bromide and cyanolxylol and recorded using a gel documentation unit. 
Table 1 In vitro callus induction in leaf explants on MS medium supplemented with different with concentrations of 2, 4 - D ( 0.5 - 2.5 $\mathrm{mg} / \mathrm{L})$, either alone or in combination BAP $(0.5-2.5 \mathrm{mg} / \mathrm{L})$ in $M$. dioica Roxb. after 4 weeks of culture.

\begin{tabular}{|ccccc|}
\hline Ms medium with plant growth regulators & $\begin{array}{c}\text { \% explants } \\
\text { responded }\end{array}$ & $\begin{array}{c}\text { Fresh Weight of callus (g) } \\
\text { (Mean } \pm \text { S.E) }\end{array}$ & Nature of callus \\
\hline $\mathbf{2 , 4} \mathbf{D}$ & BAP & 36 & $0.48 \pm 0.04^{\mathrm{a}}$ & Soft White \\
\hline $\mathbf{0 . 5}$ & -- & 48 & $0.62 \pm 0.06^{\mathrm{b}}$ & Soft White \\
\hline $\mathbf{1 . 0}$ & -- & 66 & $0.96 \pm 0.01^{\mathrm{c}}$ & Soft White \\
\hline $\mathbf{1 . 5}$ & -- & $\mathbf{7 0}$ & $\mathbf{1 . 6 8} \pm \mathbf{0 . 0 4}^{\mathbf{f}}$ & Soft White \\
\hline $\mathbf{2 . 0}$ & -- & 60 & $1.26 \pm 0.02^{\mathrm{d}}$ & Soft White \\
\hline $\mathbf{2 . 5}$ & -- & 45 & $0.49 \pm 0.01^{\mathrm{a}}$ & Friable White \\
\hline $\mathbf{0 . 5}$ & 0.5 & 55 & $0.89 \pm 0.04^{\mathrm{c}}$ & Friable White \\
\hline $\mathbf{1 . 0}$ & 1.0 & 78 & $1.42 \pm 0.07^{\mathrm{e}}$ & Friable White \\
\hline $\mathbf{1 . 5}$ & 1.5 & $\mathbf{9 4}$ & $\mathbf{1 . 8 0} \pm \mathbf{0 . 0 6}^{\mathbf{h}}$ & Friable Green \\
\hline $\mathbf{2 . 0}$ & $\mathbf{2 . 0}$ & 85 & $1.62 \pm 0.08^{\mathrm{f}}$ & Friable White \\
\hline $\mathbf{2 . 5}$ & 2.5 & & & \\
\hline
\end{tabular}

(Mean \pm SE) Five replicates per treatment; repeated thrice. Means in each column followed by same letters are not significantly different according to DMRT at $\mathrm{P}<0.05$.

Table 2 In vitro shoot regeneration via indirect organogenesis in leaf calli cultured on MS+ BAP $(1.0-5.0 \mathrm{mg} / \mathrm{L})$ either alone or in combination with L- glutamine $(2.0 \mathrm{mg} / \mathrm{L})$ in $M$. dioica Roxb. after 4 weeks of culture.

MS medium with growth regulators ( $\mathrm{mg} / \mathrm{L})$

\begin{tabular}{|c|c|c|c|}
\hline BAP & L-glutamine & $\begin{array}{l}\text { No. of shoots/explant } \\
\text { (Mean } \pm \text { S.E) }\end{array}$ & $\begin{array}{l}\text { Shoot length }(\mathrm{cm}) \\
(\text { Mean } \pm \text { S.E })\end{array}$ \\
\hline 1.0 & -- & $2.15 \pm 0.28^{\mathrm{a}}$ & $3.60 \pm 1.42^{\mathrm{j}}$ \\
\hline 2.0 & -- & $4.56 \pm 0.64^{\mathrm{c}}$ & $3.10 \pm 0.82^{\mathrm{h}}$ \\
\hline 3.0 & -- & $5.85 \pm 0.82^{\mathrm{d}}$ & $2.75 \pm 0.71^{\mathrm{g}}$ \\
\hline 4.0 & -- & $9.15 \pm 1.86^{\mathrm{g}}$ & $0.90 \pm 0.08^{a}$ \\
\hline 5.0 & -- & $6.42 \pm 0.99^{\mathrm{e}}$ & $2.80 \pm 0.65^{\mathrm{g}}$ \\
\hline 1.0 & 2.0 & $3.46 \pm 0.78^{b}$ & $2.24 \pm 0.18^{f}$ \\
\hline 2.0 & 2.0 & $5.84 \pm 0.98^{\mathrm{d}}$ & $2.16 \pm 0.17^{\mathrm{e}}$ \\
\hline 3.0 & 2.0 & $8.99 \pm 1.08^{f}$ & $1.47 \pm 0.14^{\mathrm{c}}$ \\
\hline 4.0 & 2.0 & $12.15 \pm 1.51^{\mathrm{h}}$ & $1.02 \pm 0.08^{b}$ \\
\hline 5.0 & 2.0 & $9.75 \pm 0.97^{\mathrm{g}}$ & $1.92 \pm 0.13^{\mathrm{d}}$ \\
\hline
\end{tabular}

(Mean \pm SE) Five replicates per treatment; repeated thrice. Means in each column followed by same letters are not significantly different according to DMRT at $\mathrm{P}<0.05$.

Table 3 List of RAPD primers.

\begin{tabular}{|cl|c|}
\hline S.NO & RAPD Primer & Sequence of the primer \\
\hline $\mathbf{1}$ & OPA -15 & $5^{\prime}$ - TTCCGAACCC $-3^{\prime}$ \\
\hline $\mathbf{2}$ & OPA -16 & $5^{\prime}$ - AGCCAGCGAA- 3' \\
\hline $\mathbf{3}$ & OPA -17 & $5^{\prime}$ - GACCGCTTGT- 3' \\
\hline $\mathbf{4}$ & OPA -18 & $5^{\prime}$ - AGGTGACCGT- 3' \\
\hline
\end{tabular}

Table 4 Thermocycler programming conditions.

\begin{tabular}{|l|c|cc|}
\hline Steps & Temp $\left({ }^{\circ} \mathrm{C}\right)$ & Duration & Cycle (No.) \\
\hline Initial denaturation & 94 & $3.0 \mathrm{~min}$ & $\mathbf{4 5 . 0}$ \\
\hline Denaturation & 94 & $45 \mathrm{sec}$ & $\mathbf{4 5 . 0}$ \\
\hline Annealing & 32 & $30 \mathrm{sec}$ & $\mathbf{4 5 . 0}$ \\
\hline Extension & 72 & $2.0 \mathrm{~min}$ & $\mathbf{1 . 0}$ \\
\hline \hline Final extension & $\mathbf{7 2}$ & $\mathbf{7}$ min & \\
\hline
\end{tabular}


Table 5 Number and size of DNA bands in the RAPD sex determination profile of $M$. dioica by using OPA - 15 primer.

\begin{tabular}{|c|c|c|c|c|}
\hline \multirow{2}{*}{ RAPD Primer } & \multicolumn{2}{|c|}{ Male } & \multicolumn{2}{|c|}{ Female } \\
\hline & $\begin{array}{c}\text { No. of } \\
\text { DNA bands }\end{array}$ & Size of the DNA band & $\begin{array}{c}\text { No. of } \\
\text { DNA bands }\end{array}$ & Size of the DNA band \\
\hline $\begin{array}{l}\text { OPA - } 15 \\
\text { (5'-TTCCGAACCC-3') }\end{array}$ & 3 & $\begin{array}{c}1500 \mathrm{bp} \\
1300 \mathrm{bp} \\
800 \mathrm{bp}\end{array}$ & 4 & $\begin{array}{l}1500 \mathrm{bp} \\
1300 \mathrm{bp} \\
800 \mathrm{bp} \\
700 \mathrm{bp}\end{array}$ \\
\hline
\end{tabular}

\section{Results and discussion}

\subsection{Micropropagation}

Maximum amount of mean fresh weight $(1.68 \pm 0.04 \mathrm{~g})$ of callus was observed in leaf explants cultured on MS medium supplemented with 2, 4-D $(2.0 \mathrm{mg} / \mathrm{L})$. The callus that developed from leaf explants was smooth, friable white, whereas the amount of callus was increased from leaf explants cultured on MS medium supplemented with 2, 4-D $(2.0 \mathrm{mg} / \mathrm{L})$ and in combination with BAP $(2.0 \mathrm{mg} / \mathrm{L})$ and more over that green compact callus was formed.

Maximum amount of embryogenic green compact callus with a mean fresh weight $(1.80 \pm 0.06 \mathrm{~g})$ was observed in leaf explants cultured on MS medium supplemented with 2, 4-D $(2.0 \mathrm{mg} / \mathrm{L})+\mathrm{BAP}(2.0 \mathrm{mg} / \mathrm{L})$ (figure $1-\mathrm{a})$. Maximum mean number of adventitious shoots $(12.15 \pm 1.51)$, with a mean length $(\mathrm{cm})$ of shoots $(1.02 \pm 0.08)$ was observed in leaf derived embryogenic calli subcultured on MS medium supplemented with BAP $(4.0 \mathrm{mg} / \mathrm{L})$ and L- glutamic acid $(2.0$ $\mathrm{mg} / \mathrm{L}$ ) (Table-1, figure 1- a, c). After 4 weeks of subculture these regenerated plantlets were transferred to rooting medium. Maximum number of roots (30) was observed on MS medium supplemented with IBA $3.0 \mathrm{mg} / \mathrm{L}$. After 4 weeks the regenerated plantlets were acclimatized and transferred to field conditions (Table-2, figure 1- d).

The callus that developed from leaf explants was smooth, friable white, whereas the amount of callus was increased from these explants cultured on MS medium supplemented with 2, 4-D $(2.0 \mathrm{mg} / \mathrm{L})$ and in combination with BAP $(2.0 \mathrm{mg} / \mathrm{L})$ and more over that green compact callus was formed. Similar observation were made in leaf explants (Devendra et al., 2009; Thiruvengadam \& Chung, 2011; Mustafa et al., 2012), petiole explants of $M$. dioica (Thiruvengadam et al., 2012) leaf explants of Melothria maderaspatana (Baskaran et al., 2009), nodal explants of M. charantia (Al Munsur et al., 2009).

Auxins in combination with cytokinins were found to be more efficient for the induction of green compact callus. Similar observations were made in leaf explants of $M$. dioica (Hoque et al., 2000; Nabi et al., 2002); root and leaf explants of Momordica charantia (Agarwal \& Kamal, 2004).
The callus generated from leaf explants have more regeneration capacity than the calli generated from node, internode and tendril explants of $M$. dioica. Mustafa et al. (2012) reported that callus derived from leaf and petiole explants had higher regeneration potential than callus derived from leaf and nodal explants. Highest number of shoots (12.15) regenerated on MS medium supplemented with BAP (4.0 $\mathrm{mg} / \mathrm{L})$ in combination with L-glutamine $(2.0 \mathrm{mg} / \mathrm{L})$ in leaf callus of $M$. dioica. Similarly, highest number of shoots (11.15) regenerated from nodal calli cultured on MS medium supplemented with BAP $(4.0 \mathrm{mg} / \mathrm{L})+\mathrm{L}$-glutamine $(2.0 \mathrm{mg} / \mathrm{L})$. Although cultured cells are normally capable to synthesizing all the required amino acids, the addition of certain amino acids or amino acid mixtures may be used to further stimulate cell growth. The use of amino acids is particularly important for establishing cell cultures. Amino acids provide plant cells with an immediately available source of nitrogen, which generally can be taken up by the cells more rapidly than inorganic nitrogen.

Addition of non toxic glutamine to the culture medium maintains a high growth rate of cells for longer period (Gamborg et al., 1968). The full strength MS medium containing PVP $(50 \mathrm{mg} / \mathrm{L})$ and glutamine $(40 \mathrm{mg} / \mathrm{L})$ was effective to achieve a high frequency of somatic embryo induction, maturation and further development of $M$. charantia (Thiruvengadam et al., 2006). Highest number of shoots (48 shoots) was produced on MS medium containing TDZ $(4.0 \mu \mathrm{M}), 2$, 4-D $(1.5 \mu \mathrm{M})$ in combination with Lglutamine $(0.07 \mathrm{mM})$ in internode derived callus of $M$. charantia L (Thiruvengadam et al., 2012). The addition of Lglutamine $(0.5 \mu \mathrm{M})$ resulted in the great improvement $(44.5 \%)$ of embryogenic frequency and development in suspension culture of Cucumis anguria L. (Thiruvengadam et al., 2013).

Selvaraj et al., (2007) reported that MS medium with BAP $(8.88 \mu \mathrm{M})$, NAA $(1.34 \mu \mathrm{M})$, Zeatin $(0.91 \mu \mathrm{M})$ together with Lglutamine $(136.85 \mu \mathrm{M})$ produced large number of shoots in Cucumber. Addition of L- glutamic acid in adventitious shoot regeneration medium greatly increased the production of shoots from callus. 

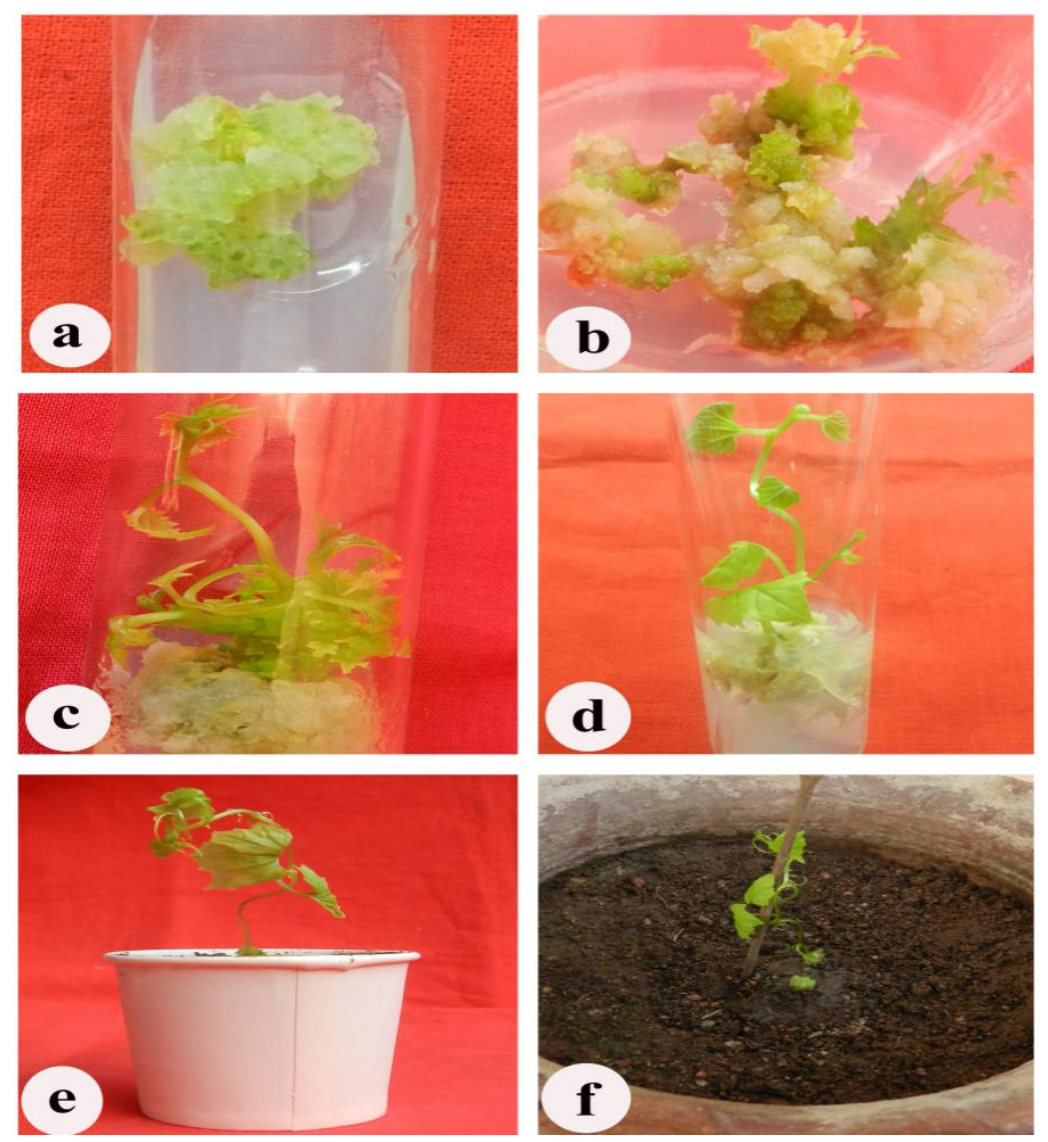

Figure 1 In vitro plantlet regeneration of spine gourd (Momordica dioica Roxb. Ex. Wild)

[(a) Induction of callus from leaf explant cultured on MS + 2, 4-D (2.0mg/L) + BAP (2.0mg/L), after two weeks of culture. (b) Multiple shoot bud induction from leaf derived callus on MS + BAP $(4.0 \mathrm{mg} / \mathrm{L})+\mathrm{L}$-glutamine $(2.0 \mathrm{mg} / \mathrm{L})$, after three weeks of the culture. (c) Shoot elongation on MS basal medium, after 2 weeks of culture (d) Rooting of shoot on MS + IBA (3.0 mg/L), after two weeks of the culture (e) Hardening of the plantlet in a plastic cup. (f) Acclimatization of plantlet in a pot].

This is in agreement with the findings of Selvarj et al., (2002) for Cucumis sativus. Maximum number of adventitious shoots regenerated on MS medium fortified with BA $(2.0 \mu \mathrm{M})$, TDZ $(4.0 \mu \mathrm{M}), 10 \% v / v$ coconut water, and in combination with Lglutamine $(0.08 \mathrm{mM})$ in petiole derived callus of Melothria maderaspatana (Baskaran et al., 2009).

Devendra et al. (2009) reported that highest shoot regeneration (12.33 shoots) was observed on MS medium supplemented with BAP $(1.5 \mathrm{mg} / \mathrm{L})$ in combination with $\mathrm{Kn}(1.5 \mathrm{mg} / \mathrm{L})$ in leaf derived calli of $M$. dioica. According to Debnath et al., (2013) requirement of high cytokinin (BAP $4.0 \mathrm{mg} / \mathrm{L}$ ) and coconut milk $(15 \% \mathrm{v} / \mathrm{v})$ in nodal callus culture clearly indicate that the differential morphogenetic potentiality of the three explants. The reported result is significant in terms of high shoot ( $86 \pm 3.44$ shoot buds) was found on the 126 days of culture on the same inductive medium for further multiplication and growth.

3.2 Molecular Confirmation of Sex in Regenerated Plantlets of Spine gourd

\subsubsection{RAPD - PCR amplification analysis:}

Four RAPD primers namely OPA-15, OPA-16, OPA-17, OPA18 were utilized for PCR amplification of genomic DNA isolated from leaf tissue of male and female spine gourd in vivo and randomly selected in vitro regenerated plants. Out of four primers used, OPA-15 produced distinct bands in male and female plants. 


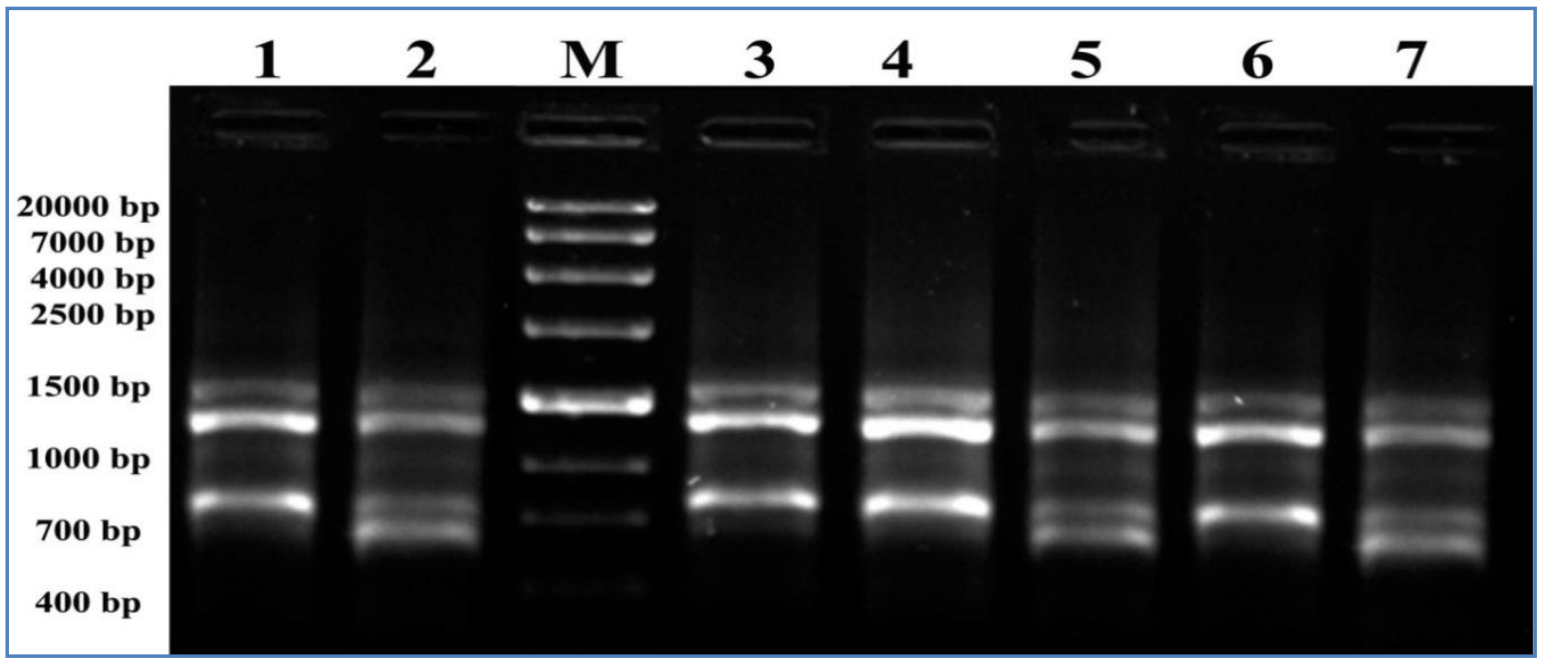

Figure 2 RAPD profile for the confirmation of sex in in vitro regenerated plantlets of $M$. dioica by comparing in vivo male and female mother plants amplified with OPA-15 primer.

[Lane. M: Marker - Lane 1: Male mother plant (in vivo), Lane 2: Female mother plant (in vivo), Lane 3, 4 \& 6: Male regenerated plant (In vitro), Lane 5 \& 7: Female regenerated plant (In vitro) ]

\subsubsection{Primer:}

OPA-15 primer with the primer sequence 5'-TTCCGAACCC3' was amplified genomic DNA samples of in vivo and in vitro developed male and female plants of $M$. dioica. Three DNA bands, sized $1500 \mathrm{bp}, 1300 \mathrm{bp}$ and $800 \mathrm{bp}$ in male samples, whereas, four DNA bands, sized $1500 \mathrm{bp}, 1300 \mathrm{bp}, 800 \mathrm{bp}$ and $700 \mathrm{bp}$ in female samples was observed, respectively (Table 5, figure 2).

The family Cucurbitaceae have different types of sex forms i.e. bisexuality, monoecious and dioecious types. Particularly in dioecious plants identification of sex in seedling stages of plant is very important for selection of medicinally important female plants for large scale cultivation. This could be very useful for the farmer that they need not to wait until flowering stage occur to select the staminate and pistillate plants.

According to Renner \& Ricklefs (1995) nearly 6\% angiosperms are dioecious throughout the world. In Cucurbitaceae, the sex of an individual is difficult to determine at the early stages of development, particularly before flowering. This is very important for breeding programmers to develop new varieties.

In present study it was observed that among all the four RAPD primers OPA-15 primer (5'-TTCCGAACCC-3') produced a unique band of $700 \mathrm{bp}$ in size appeared only in female samples (Pic-2, lanes 2, 4 and 6), while it is absent in male samples (Pic-2, lanes 1, 3 and 5). This unique 700 bp DNA band was highly reproducible under a broad range of amplification conditions. Therefore OPA - 15 primer can be used as a differential marker to identify female plants from male plants at pre flowering stage.
Similar type of effort for sex determination in $M$. dioica using RAPD marker OPA-15 had done earlier by Patil et al. (2012) and Baratakke et al. (2013). They reported the presence of 1500 bp unique band in male while a $900 \mathrm{bp}$ unique band in female samples. But in present investigation this unique band was reported at $700 \mathrm{bp}$ in female samples of $M$. dioica by using the same OPA -15 primer. The variation in the results may be due to biotype variation, environmental and ecological difference between Telangana region and north Indian region.

Baratakke et al. (2013) used the SCAR marker for the identification sex in $M$. dioica at pre-flowering stage. In cucurbits female sex- associated RAPD marker in pointed gourd (Trichosanthes dioica Roxb.) has been also reported by Singh et al. (2002).

There are several reports on sex determination in dioecious plants. Sex determination in papaya by using PCR based RAPD molecular marker was reported by several authors from various countries like in Japan (Ursaki et al., 2002), Hawaii (Deputy et al., 2002), Brazil (Lemos et al., 2002) and India (Parasnis et al., 1999). In Salix viminalis (Alstrom-Rapaport et al., 1998), Encephalartos natalensis (Prakash \& Staden, 2006), Borassus flabellifer (George et al., 2007), Simmondsia chinensis (Agrawal et al., 2007) and Pandanus fasciculalris (Vinod et al., 2007) also sex is determined by using PCR based RAPD molecular marker.

\section{Acknowledgements}

The authors are grateful to University Grants Commission, New Delhi, India for their financial assistance in the form of 
Major Research Project (F. No. 37- 237/2009 (SR); dated $12 / 01 / 2010$ and 28/05/2012).

\section{Conflict of interest}

Authors would hereby like to declare that there is no conflict of interests that could possibly arise.

\section{References}

Aberoumand A, Deokule SS (2009) Studies on nutritional values of some wild edible plants from Iran and India. Pakistan Journal of Nutrition 8: 26-31.

Agarwal M, Kamal R (2004) In Vitro clonal propagation of Momordica charantia L. Indian Journal of Biotechnology 3: 426-430.

Agrawal V, Sharma K, Gupta S, Kumar R, Prasad M (2007) Identification of sex in Simmondsia chinensis (Jojoba) using RAPD marker. Plant Biotechnology Reports 1: 207-210. doi: 10.1007/s 1 1816-007-0031-6.

Al Munsur MAZ, Haque MS, Nasiruddin KM, Hossain MS (2009) In Vitro propagation of bitter gourd (Momordica charantia L.) from nodal and root segments. Plant Tissue Culture and Biotechnology 19: 45-52. DOI: http://dx.doi.org/10.3329/ptcb.v19i1.4916.

Alstrom-Rapaport C, Lascoux M, Wang YC, Roberts G, Tuskan GA (1998) Identification of a RAPD marker linked to sex determination in the basket willow (Salix viminalis L.). Journal of Heredity 89: 44-49. doi: 10.1093/jhered/89.1.44.

Baratakke RC, Patil CG, Poornima B, Sankannavar SH (2013) Molecular tool for sex identification (female) in Momordica dioica Roxb. with reference to Medicinal values. International journal of Research in Aurveda and Pharmacy 4: 487-490. doi:10.7897/2277-4343.04404.

Baskaran P, Velayutham P, Jayabalan $\mathrm{N}$ (2009) In vitro regeneration of Melothria maderaspatana via indirect organogenesis. In Vitro Cellular \& Developmental BiologyPlant 45: 407-413. doi: 10.1007/s11627-008-9172-8.

Bawara B, Dixit M, Chauhan NS, Dixit VK, Saraf DK (2010) Phyto-Pharmacology of Momordica dioica Roxb. ex. wild: A Review. International Journal of Phytomedicine 2:01-09. doi: http://dx.doi.org/10.5138/ijpm.v2i1.79.

De Wilde WJJO, Duyfjes BEE (2002) Synopsis of Momordica (Cucurbitaceae) in SE Asia and Malaysia. Botany Zhurn 87: 132-148.

Debnath B, Sinha S, Sinha RK (2013) Rapid In Vitro differentiation and regeneration of Momordica dioica Roxb. Indian Journal of Plant Sciences 2: 43-47.
Deputy JC, Ming R, Ma H, Liu Z, Fitch MM, Wang M, Manshardt R, Stiles JI (2002) Molecular markers for sex determination in papaya (Carica papaya L.). Theoretical and Applied Genetics 106: 107-111. doi: 10.1007/s00122-0020995-0.

Devendra NK, Subhash B, Seetharam YN (2009) Callus growth and plant regeneration in Momordica dioica (Roxb.) Willd. Cucurbitaceae. American and Eurasian Journal of Sustainable Agriculture 3:743-748.

Doyle JJ, Doyle JL (1990) Isolation of plant DNA from fresh tissue. Focus 12: 1241-1251.

Gamborg OL, Miller RA, Ojima K (1968) Nutrient experiments of suspension culture of soybean root callus. Experimental Cell Research 80: 150-158.

George J, Karun A, Manimekalai R, Rajesh MK, Remya P (2007) Identification of RAPD markers linked to sex determination in palmyrah (Borassus flabellifer L.). Current Science 93: 1075-1077.

Gopalan C, Shastri BV, Balasubramanian SC (1994) Nutritive value of Indian Foods. NIN, ICMR, Hyderabad, India.

Hoque A, Islam R, Arima S (2000) High frequency plant regeneration from cotyledon-derived callus of Momordica dioica (Roxb.) Willd. Phytomorphology 50: 267-272.

Jain A, Singhai AK (2010) Effect of Momordica dioica Roxb. on gentamicin model of acute renal failure. Natural Products Research 24:1379-1389. doi: 10.1080/14786410802267569.

Joseph JK (2005) Studies on ecogeography and genetic diversity of the genus Momordica L. in India. M. Sc. Dissertation submitted to Mahatma Gandhi University, Kottayam, Kerala, India.

Joseph JK, Antony VT (2008) Ethnobotanical investigations in the genus Momordica L. in the Southern Western Ghats of India. Genetic Resources and Crop Evolution 55:713 - 721. doi: 10.1007/s10722-007-9279-5.

Kumar U, Prajapati ND (2003) Agro's Dictionary of Medicinal Plants. Agrobios (India), Agrohouse Jodhpur, India, pp 216.

Lemos EGM, Silva CLSP, Zaidan HA (2002) Identification of sex in Carica papaya L. using RAPD markers. Euphytica 127: 179-184. doi: 10.1023/A:1020269727772.

Murashige T, Skoog F (1962) A Revised Medium for Rapid Growth and Bio Assays with Tobacco Tissue Cultures. Physiologia Plantarum, 15: 473-497. doi: 10.1111/j.13993054.1962.tb08052.x.

Mustafa Md, Swamy TN, Raju S, Peer Mohammad SK, Suresh V (2012) Regeneration of Plantlets from nodal cultures of 
Momordica dioica Roxb. International Journal of Pharma and Bio Science 3: 92-96.

Nabi SA, Rashid MM, Al-Amin M, Rasul MG (2002) Organogenesis in teasle gourd (Momordica dioica Roxb.). Plant tissue culture 12: 173-180.

Parasnis AS, Ramakrishna W, Chowdari KV, Grupta VS, Ranjekar PK (1999) Microsatellite (GATA) reveals sex-specific differences in papaya. Theoretical and Applied Genetics 99: 1047-1052. doi: 10.1007/s001220051413.

Patil CG, Baratakke RC, Sandigwad AM (2012) Development of a RAPD-based SCAR marker for sex identification in Momordica dioica Roxb. Israel Journal of Plant Sciences 60: 457-465. doi: 10.1560/IJPS.60.4.457.

Prakash S, Staden JV (2006) Sex identification in Encephalartos natalensis (Dyer and Verdoorn) using RAPD markers. Euphytica 152: 197-200. http://dx.doi.org/10.1007/ s10681-006-9198-0.

Ram D, Kumar S, Verma A, Rai M (2004) Variability analysis of underutilized nutritive vegetable Kartoli: Indian collection. Cucurbit Genetics Cooperative Report 27: 66-68.

Renner SS, Ricklefs RE (1995) Dioecy and Its Correlates in the Flowering Plants. American Journal of Botany 82: 596606.

Sastri BN (1962) Wealth of India-Raw Materials. Council of Scientific and Industrial Research, Delhi, 406-407.

Selvaraj N, Vasudevan A, Manickavasagam M, Kasthrirengan S, Ganapathi A (2007) High frequency shoot regeneration from cotyledon explants of cucumber via organogenesis. Scientia Horticulture 112: 2-8. doi:10.1016/j.scienta.2006.12.037.

Selvaraj N, Vengadesan G, Vasudevan A, Prem Anand R, Ramesh Anbazhagan V Ganapathi, A (2002) Micropropagation of Cucumis sativus L. from field grown plants. In: Maynard DN (Ed.). Proceedings of the Cucurbitaceae 2002, ISHS Press, Belgium Pp 149-156.

Singh M, Kumar S, Singh AK, Ram D, Kalloo G (2002) Female sex-associated RAPD marker in pointed gourd (Trichosanthes dioica Roxb.). Current Science 82: 131-132.

Thiruvengadam M, Chung IM (2011) Establishment of an efficient Agrobacterium tumefaciens-mediated leaf disc transformation of spine gourd (Momordica dioica Roxb. ex Willd). African Journal of Biotechnology 10: 19337-19345.

Thiruvengadam M, Jeyakumar JJ, Kamaraj M, Lee YJ, Chung IM (2013) Plant regeneration through somatic embryogenesis from suspension cultures of gherkin (Cucumis anguria L.). Australian Journal of Crop Science 7: 969-977.

Thiruvengadam M, Mohamed SV, Yang CH, Jayabalan N (2006) Development of an embryogenic suspension culture of bitter melon (Momordica charantia L.). Scientia horticulturae 109: 123-129. doi:10.1016/j.scienta.2006.03.012.

Thiruvengadam M, Praveen N, Chung IM (2012) In vitro regeneration from internodal explants of bitter melon (Momordica charantia L.) via indirect organogenesis. African Journal of Biotechnology 11: 8218-8224. DOI: 10.5897/AJB12.252.

Urasaki N, Tokumoto M, Tarora K, Ban Y, Kayano T, Tanaka H, Oku H, Chinen I, Terauchi R (2002) A male and hermaphrodite specific RAPD marker for papaya (Carica papaya L.). Theoretical and Applied Genetics 104: 281-285. doi: 10.1007/s001220100693.

Vinod MS, Raghavan PS, George S, Parida A (2007) Identification of sex - specific SCAR marker in dioecious Pandanus fascicularis L. (Pandanaceae). Genome 50: 834-839. 